\title{
Akciğer dışı klinik örneklerden Mycobacterium tuberculosis kompleks tanımlanmasında moleküler yöntemlerin değerlendirilmesi
}

\author{
Nazmiye ÜNLÜ (ID) \\ Rabia CAN \\ SARINOĞLU(ID) \\ Nurcan DUMAN(ID) \\ Uğur KÜÇÜKSU(ID) \\ Ayşegül KARAHASAN \\ YAĞCI(ID)
}

Marmara Üniversitesi Pendik Eğitim ve Araştırma Hastanesi, Tıbbi Mikrobiyoloji Kliniği, İstanbul, Türkiye

Clinic of Medical Microbiology, University of Marmara Pendik Training and Research Hospital, Istanbul, Turkey

*Bu makale 2019 Uluslararası Mikobakteri Sempozyumu'nda (2018 verileri) sözlü sunum olarak sunulmuştur.

ÖZ

Akciğer dışı klinik örneklerden Mycobacterium tuberculosis kompleks tanımlanmasında moleküler yöntemlerin değerlendirilmesi

Giriş: En yaygın ve ölümcül bulaşıcı hastalıklardan biri olan tüberküloz, en sık akciğerleri etkilemekle birlikte tüm doku ve organları tutabilir. Akciğer dışı tüberküloz tanısı akciğer tüberkülozundan daha zor olabilir ve bu durum tedaviye başlamada gecikmeye yol açabilir. Çalışmamızda, tüberkülozun erken ve hızlı tanısında kullanılan FluoroType MTB, GeneXpert MTB/RIF, GeneXpert MTB/RIF Ultra moleküler testlerinin akciğer dışı örneklerde tanısal değerinin belirlenmesi amaçlanmıştır.

Materyal ve Metod: Laboratuvarımıza gönderilen akciğer dışı klinik örneklerde; aside dirençli basil mikroskopisi (Kinyoun boyama) ve kültür (Lowenstein Jensen ve BACTEC MGIT 960 otomatize kültür sistemi-BD) sonuçları OcakAralık 2018 tarihleri arasında çalışılan FluoroType MTB ve GeneXpert MTB/ RIF sonuçları ve Ocak-Aralık 2019 tarihleri arasında çalışılan FluoroType MTB ve GeneXpert MTB/RIF Ultra sonuçlarıyla karşılaştırılmıştır.

Bulgular: Toplam 892 adet akciğer dışı örnek çalışmaya dahil edilmiştir. 2018 yılında, 467 örneğin 16 (\%3,4)'sında moleküler yöntemler ile pozitiflik saptanmıştır. Kültür ile kıyaslandığında, FluoroType MTB'nin duyarlıı̆ğ \%76,92, özgüllüğ̈̈ \%98,88; GeneXpert MTB/RIF'in duyarlılığı \%100, özgüllüğü $\% 98,96$ olarak belirlenmiştir.

2019 yılında, 425 klinik örneğin 15 (\%3,5)'inde moleküler yöntemler ile pozitiflik saptanmıştır. Kültür ile kıyaslandığında, FluoroType MTB'nin duyarlıığı \% 62,5, özgüllüğü \% 98,05; GeneXpert MTB/RIF Ultra'nın duyarlılığı \% 100, özgüllüğü \%99,36 olarak belirlenmiştir.

Sonuç: Tanıda altın standart yöntem kültür olsa da kültür negatif yedi vakada hastanın kliniği, radyoloji ve patoloji sonuçları ile desteklenerek, polimeraz 
zincir reaksiyonu (PCR) pozitifliği ile tüberküloz tanısı koyulmuştur. Akciğer dışı örneklerde tüberküloz tanısı, akciğer örneklerine kıyasla düşük basil yükü, çoğunlukla invaziv yöntemlerle elde edilmesi gibi nedenlerle daha zordur. Moleküler yöntemlerin erken ve hızlı tanı koymada kritik rol oynadığı göz önünde bulundurulmalıdır.

Anahtar kelimeler: Akciğer dışı tüberküloz; FluoroType MTB; GeneXpert MTB/RIF; GeneXpert MTB/RIF Ultra

\section{ABSTRACT}

Evaluation of the molecular assays for detection of Mycobacterium tuberculosis complex in extrapulmonary specimens

Introduction: Tuberculosis, one of the most common and deadly infectious diseases, mainly affects the lungs, but can involve all tissues and organs. Diagnosis of extrapulmonary tuberculosis may be more challenging than pulmonary tuberculosis, which may lead to delay in starting treatment. In our study, it was aimed to determine the diagnostic value of FluoroType MTB, GeneXpert MTB/RIF, GeneXpert MTB/RIF Ultra molecular tests in extrapulmonary specimens.

Materials and Methods: Extrapulmonary clinical materials were subjected to Kinyoun staining for acid fast bacilli and cultivation was done on Lowenstein Jensen media and BACTEC MGIT 960 automated culture system (BD). Results were compared with FluoroType MTB and GeneXpert MTB/RIF test results (2018) and with FluoroType MTB and GeneXpert MTB/RIF Ultra tests results (2019).

Results: A total number of 892 extrapulmonary specimens were enrolled in the study. In 2018, positivity was detected in 16 (3.4\%) of 467 specimens by molecular methods. Compared with culture; the sensitivity and specifity of the FluoroType MTB were $76.92 \%$, 98.88\% respectively; the sensitivity and specifity of GeneXpert MTB/RIF were 100\%, 98.96\% respectively. In 2019, positivity was detected in 15 (3.5\%) of 425 specimens by molecular methods. The sensitivity and specifity of the FluoroType MTB was $62.5 \%$, 98.05\% respectively; the sensitivity and specificity of GeneXpert MTB/RIF Ultra was 100\%, 99.36\% respectively.

Conclusion: Although culture is the gold standard method in the diagnosis of tuberculosis, the patients were diagnosed only with polymerase chain reaction positivity, supported by the patient's clinical, radiology and pathology results in seven cases. The diagnosis of tuberculosis in extrapulmonary specimens is more challenging than in pulmonary specimens due to low bacillary burden and requiring invasive procedures for sampling. It should be considered that molecular methods have a critical role in diagnosis.

Key words: Extrapulmonary tuberculosis; FluoroType MTB; GeneXpert MTB/RIF; GeneXpert MTB/RIF Ultra

\section{GiRiş}

Tüberküloz, sıklıkla akciğeri tutmakla birlikte tüm doku ve organları etkileyebilen, benign ve malign birçok hastalığı taklit edebilen bir enfeksiyon hastalığıdır. Akciğer dışı tüberkülozda tutulum yüzeyel ve derin lenf nodlarında, plevra, kemik ve eklemlerde, gastrointestinal ve genitoüriner organlarda olabilmektedir (1). Dünya Sağlık Örgütü’nün 2019 Küresel Tüberküloz Raporu'nda, dünyada 2018'deki tüberküloz vakalarının \%15'ini akciğer dışı tüberküloz vakalarının oluşturduğu raporlanmıştır (2). Halk Sağlığı Genel Müdürlüğü’nün Türkiye'de Verem Savaş 2019 Raporu'na göre; 2017 yılında verem savaş dispanseri kayıtlarına giren 12.046 tüberküloz hastasının \%60,9 (7.332)'u akciğer tutulumu, \%33,9 (4.078)'u akciğer dışı tutulum ve \%5,3 (636)'ü hem akciğer hem de akciğer dışı tutulum göstermiştir (3). Akciğer dışı organ tutulumu azımsanmayacak bir orana sahiptir. Mikroskopiye göre duyarlılığı yüksek olan nükleik asit amplifikasyon testlerinin geliştirilmesiyle akciğer dışı tüberküloz tanısında ve hastayı izole etme, tedaviye başlama sürecinin kısaltılmasında önemli gelişme kaydedilmiştir $(4,5)$.

Bu çalışmada, hastanemiz Tıbbi Mikrobiyoloji Laboratuvarı'na tüberküloz tanısı için gönderilen akciğer dışı örneklerde moleküler testlerden FluoroType MTB, GeneXpert MTB/RIF\&Ultra test sonuçlarının kültür ve mikroskopi sonuçlarıyla karşılaştırılması amaçlanmıştır.

\section{MATERYAL ve METOD}

Ocak 2018-Aralık 2019 tarihleri arasında hastanemiz Tıbbi Mikrobiyoloji Laboratuvarı'na tüberküloz tanısı için gönderilen 1.127 klinik örnek çalışmaya dahil edilmiştir. Çalışma için etik kurul izni alınmıştır (Protokol No: 676). Klinik örneklerde aside dirençli basil (ARB) mikroskopisi (Kinyoun boyama) ve kültür (Lowenstein Jensen ve BACTEC MGIT 960 otomatize kültür sistemi-BD) konvansiyonel yöntemlerle çalışılmıştır. Beyin omurilik sıvısı (BOS) ve idrar örneklerinin moleküler tanısı için 2018 yılında GeneXpert MTB/RIF (Cepheid, Sunnyvale, Kaliforniya), 2019 yılında ise GeneXpert MTB/RIF Ultra (Cepheid, Sunnyvale, Kaliforniya) kullanılmıştır. Diğer örnekler (Plevral, peritoneal, perikardiyal sıvılar, vitröz sıvı, eklem sıvısı gibi steril vücut sıvıları, doku, apse, kemik iliği) FluoroType MTB (HAIN Lifesciences) ile çalışılmıştır.

\section{FluoroType MTB Testi}

FluoroType MTB, N-Asetil-L-Sistein+Sodyum hidroksit yöntemi ile işlenmiş klinik örneklerde HyBeacon tek- 
nolojisi kullanılarak gerçek zamanlı PCR ile Mycobacterium tuberculosis kompleks (MTC) DNA'sının kalitatif olarak saptandığı bir in vitro testtir. Dekontaminasyon işleminden sonra örnekler fosfat tamponunda yeniden süspanse edilmiş; işlenmiş örneklerden FluoroLyse kiti ile manuel DNA ekstraksiyonu yapılmıştır. Polimeraz ve primerleri içeren amplifikasyon karışımları (AM-A, AM-B) ile ekstrakte edilmiş DNA'dan solüsyon hazırlanarak FluoroCycler cihazında amplifikasyon, fluorofor işaretli HyBeacon probları ile hibridizasyon ve erime eğrisi analizi sonucunda elde edilen pikler değerlendirilmiştir $(6,7)$.

\section{GeneXpert MTB/RIF (Xpert MTB/RIF) Testi}

Semi-nested gerçek zamanlı PCR yöntemi ile klinik örneklerde MTC DNA'sının semikantitatif olarak saptanması ve rpoB gen bölgesi değerlendirilerek rifampisin direncinin saptanmasında kullanılan nükleik asit amplifikasyon testidir. FluoroType MTB'deki gibi ekstra bir DNA ekstraksiyonu basamağı olmadığından daha az teknik donanım gerektirmektedir. Tek kullanımlık, kapalı kartuş sistemi ile örnekler arası çapraz kontaminasyon riski azdır $(8,9)$. Laboratuvarımızda BOS ve idrar örnekleri GeneXpert MTB/RIF sisteminde çalışılmıştır.

\section{GeneXpert MTB/RIF Ultra (Xpert Ultra) Testi}

Xpert MTB/RIF ile aynı GeneXpert platformunun kullanıldığı, MTC saptama duyarlılığının artırılmasını amaçlayan yeni jenerasyon bir nükleik asit amplifikasyon testidir. Bu amaçla iki farklı amplifikasyon hedef bölgesi (IS6110 ve IS1081) daha eklenmiştir ve alt saptama limiti $131 \mathrm{cfu} / \mathrm{ml}^{\prime} \mathrm{den} 16 \mathrm{cfu} / \mathrm{ml}^{\prime}$ ye indirilmiştir. 2017 yılında Dünya Sağlık Örgütü, Xpert Ultra'nın artmış saptama duyarlılığına dayanarak Xpert MTB/RIF'in yerine kullanılabileceğine dair rapor yayınlamışıı (10). 2019 Ocak ayından itibaren laboratuvarımızda Xpert Ultra sistemine geçilmiş̧ir.

Laboratuvarımızda başlıca akciğer örnekleri ve akciğer dışı örneklerden de BOS ve idrar Xpert MTB/ RIF\&Ultra ile çalışılmıştır. FluoroType MTB ile örnekler haftada bir kez çalışıldığından, yüksek mortalite ve morbiditeye neden olabilen tüberküloz menenjiti tablosunda tanıda gecikmeye neden olmamak için BOS örneklerinde Dünya Sağlık Örgütü'nün de tüberküloz menenjiti tanısında başlangıç testi olarak önerdiği Xpert MTB/RIF\&Ultra sistemi tercih edilmiştir (10). İdrar örneklerinde viskositenin düşük olup, kartuşta tıkanmaya yol açmayan yapısı nedeniyle pratik yaklaşım olarak Xpert MTB/RIF\&Ultra sistemi tercih edilmiştir.

\section{BULGULAR}

2018 yılında laboratuvarımızda çalışılıp sonuçlarına ulaşılabilen 535 klinik örnekten 467'si, 2019 yılında 592 klinik örnekten 425'i olmak üzere toplamda 892 adet örnek çalışmaya dahil edilmiştir. 2018 yılında 16 $(\% 3,4), 2019$ yılında $15(\% 3,5)$ örnekte moleküler yöntemler ile pozitiflik saptanmıştır. Örneklerin dağılımı Tablo 1 ve Tablo 2'de gösterilmiştir.

2018 yılına ait örneklerde; FluoroType MTB'nin kültür ile kıyaslandığında duyarlılığı \%76,92 (\%95 GA; $\% 46,19-\% 94,96)$, özgüllüğü \%98,88 (\%95 GA; $\% 97,16-\% 99,69)$ bulunmuştur. Xpert MTB/RIF'in kültür ile kıyaslandığında duyarlılığı \%100 (\%95 GA; \%2,5-\%100), özgüllüğü \%98,96 (\%95 GA; \%94,33$\% 99,97)$ bulunmuştur. 2019 yılına ait örneklerde FluoroType MTB'nin kültür ile kıyaslandığında duyarlılı̆̆ı \%62,5 (\%95 GA; \%24,49-\%91,48), özgüllüğü \%98,05 (\%95 GA; \%95,5-\%99,36); Xpert Ultra'nın kültür ile kıyaslandığında duyarlılığı \%100 (\%95 GA;

Tablo 1. 2018 yılında moleküler yöntemler ile pozitiflik saptanan örneklerin dağılımı

\begin{tabular}{lcc|}
\hline Örnek tipi & Örnek sayısı (\%) & FluoroType MTB (+) $(\mathbf{\%})$ \\
\hline Steril vücut sıvıSı & $276(59,1)$ & $4(0,8)$ \\
Apse & $50(10,7)$ & $4(0,8)$ \\
Doku & $38(8,1)$ & $6(1,4)$ \\
Kemik iliği & $6(1,4)$ & $0(0)$ \\
Örnek tipi & Örnek sayısı (\%) & $2(0,4)$ \\
BOS & $64(13,7)$ & $0(0)$ \\
İrar & $33(7)$ & $16(3,4)$ \\
Toplam & $467(100)$ &
\end{tabular}


Tablo 2. 2019 yılında moleküler yöntemler ile pozitiflik saptanan örneklerin dağılımı

\begin{tabular}{|lcc|}
\hline Örnek tipi & Örnek sayısı (\%) & FluoroType MTB (+) (\%) \\
\hline Steril vücut sıvıSı & $191(45)$ & $4(0,9)$ \\
Apse & $42(9,9)$ & $3(0,7)$ \\
Doku & $25(5,8)$ & $3(0,7)$ \\
Kemik iliği & $6(1,4)$ & $0(0)$ \\
Örnek tipi & Örnek sayısı (\%) Xpert Ultra (+) (\%) \\
BOS & $85(20)$ & $3(0,7)$ \\
İdrar & $76(17,9)$ & $2(0,5)$ \\
Toplam & $425(100)$ & $15(3,5)$ \\
\hline (+): Pozitif, Xpert Ultra: GeneXpert MTB/RIF Ultra. & & \\
\hline
\end{tabular}

Tablo 3. 2018 PCR sonuçlarının yayma ve kültür sonuçları ile karşılaştırılması

\begin{tabular}{|lccccc|}
\hline & \multicolumn{3}{c}{ Kültür } & \multicolumn{2}{c|}{ ARB } \\
\cline { 3 - 6 } PCR & & Pozitif $(\%)$ & Negatif (\%) & Pozitif (\%) & Negatif (\%) \\
\hline \multirow{2}{*}{ FluoroType MTB } & Pozitif (\%) & $10(2,1)$ & $4(0,9)$ & $4(0,9)$ & $10(2,1)$ \\
& Negatif (\%) & $3(0,6)$ & $353(75,6)$ & $0(0)$ & $356(76,2)$ \\
\multirow{2}{*}{ Xpert MTB/RIF } & Pozitif (\%) & $1(0,2)$ & $1(0,2)$ & $0(0)$ & $2(0,4)$ \\
\multirow{2}{*}{ Toplam (\%) 467 (100) } & Negatif (\%) & $0(0)$ & $95(20,4)$ & $0(0)$ & $95(20,4)$ \\
\hline \multicolumn{2}{l}{ PCR: Polimeraz zincir reaksiyonu, ARB: Aside dirençli basil, Xpert MTB/RIF: GeneXpert MTB/RIF. } \\
\hline
\end{tabular}

Tablo 4. 2019 PCR sonuçlarının yayma ve kültür sonuçları ile karşılaştırılması

\begin{tabular}{|lccccc|}
\hline & & \multicolumn{3}{c|}{ Kültür } & ARB \\
\cline { 3 - 6 } PCR & & Pozitif $(\%)$ & Negatif (\%) & Pozitif (\%) & Negatif (\%) \\
\hline \multirow{2}{*}{ FluoroType MTB } & Pozitif (\%) & $5(1,2)$ & $5(1,2)$ & $2(0,5)$ & $8(1,8)$ \\
& Negatif (\%) & $3(0,7)$ & $251(59,1)$ & $0(0)$ & $254(59,8)$ \\
\multirow{2}{*}{ Xpert Ultra } & Pozitif (\%) & $4(0,9)$ & $1(0,2)$ & $0(0)$ & $5(1,2)$ \\
& Negatif (\%) & $0(0)$ & $156(36,7)$ & $0(0)$ & $156(36,7)$ \\
Toplam (\%) & 425 (100) & $12(2,8)$ & $413(97,2)$ & $2(0,5)$ & $423(99,5)$ \\
\hline PCR: Polimeraz zincir reaksiyonu, ARB: Aside dirençli basil, Xpert Ultra: GeneXpert MTB/RIF Ultra. & & \\
\hline
\end{tabular}

\%39,76-\%100), özgüllüğü \%99,36 (\%95 GA; \%96,5\%99,98) bulunmuştur.

PCR sonuçları, yayma ve kültür ile kıyaslandığında, yayma pozitif örneklerin tamamında PCR ile de pozitiflik saptandığı ancak 2018 ve 2019 yıllarında üçer örnekte kültürde MTC saptanıp, PCR'de saptanamadığı görülmektedir (Tablo 3 ve 4). Bu örneklerin dördü periton sıvısı, biri plevra sıvısı, biri doku örneğidir. Altı hastaya da takip eden klinik tarafından antitüberküloz tedavi başlanmıştır.
2018 yılında beş, 2019 yılında altı örnekte ise, MTC kültürle saptanamayıp PCR'de saptanmıştır (Tablo 3 ve 4). Bu örneklerden beşi apse, ikisi doku, ikisi BOS, biri periton sıvısı, biri periton biyopsi örneğidir. Yayma ve kültür negatif olmasına rağmen doku örneğinde pozitiflik saptanan iki hastada; hastaların kliniği ve patoloji raporu tüberküloz ile uyumlu olduğundan, antitüberküloz tedavi başlanmış ve hastalar tedaviden fayda görmüşlerdir. Sadece PCR pozitif olan beş apse örneği irdelendiğinde; bir hastadan antitüberküloz tedavi alırken örnek gönderildiği, bir 
hastanın Crohn tanısı ile opere edildiği, diğer üç hastanın ise klinik ve radyolojik bulgularının tüberküloz ile uyumlu olması, quantiferon testinde pozitiflik saptanması nedeniyle başlanan antitüberküloz tedaviden fayda gördükleri kaydedilmiştir.

Periton biyopsi örneği alınan hastanın batın görüntülemesi omental kek (Tüberküloz peritoniti? Peritoneal karsinomatozis?) olarak raporlanmış olup, hastanın kliniği ve patoloji sonucunun tüberküloz ile uyumlu bulunması nedeniyle başlanan antitüberküloz tedaviden fayda görmüştür. Periton sIvısında PCR pozitif, yayma ve kültür negatif olan hasta; kliniği ve laboratuvar sonuçları ile Hepatit B enfeksiyonuna bağ karaciğer sirozu tanısı almış, PCR sonucu yanlış pozitif olarak değerlendirilmiştir.

BOS örneklerinde yayma ve kültür negatif, PCR pozitif saptanan bir hastada radyoloji miliyer tüberküloz ile uyumlu bulunmuş ve menenjit semptomları olan hastaya antitüberküloz tedavi başlanmış, hastanın kliniğinde düzelme olduğu görülmüştür. İkinci hasta acil servise progresif menenjit semptomları ile başvurmuş ve alınan BOS örneği yetersiz olduğu için kültür olmaksızın sadece PCR pozitifliği ile antitüberküloz tedavi başlanmış; tedavinin sekizinci gününde eş zamanlı gönderilen BOS örneğinde kültür ve mikroskopi negatif, PCR pozitif saptanmıştır.

\section{TARTIŞMA}

Bu çalışmada 2018-2019 yıllarında akciğer dışı örneklerde moleküler testlerin tanısal etkinliği değerlendirilmiş ve klinisyenin laboratuvar ve klinik veriler ile izlediği hastaların tedavi süreçleri de takip edilmiş̧ir. Perez-Risco ve arkadaşları; 108 yayma negatif, kültür pozitif akciğer dışı örnekte Xpert Ultra'nın duyarlılığını doku örneklerinde \%86,6, BOS ve idrar örneklerinde $\% 100$, apse örneklerinde $\% 64,7$ saptamış olup, plevra sıvısı örneklerinde ise $\% 47,6$ olarak saptamıştır. MTC DNA'sını tespit etmede plevra sıvısının optimal bir örnek olmadığı belirtilmiştir (11). Liu ve arkadaşları, tüberküloz peritoniti semptomu olan 191 hasta örneğinde Xpert MTB/RIF sistemi ile peritoneal sıvıda MTC DNA'sını saptama duyarlılığını $\% 18,3$ olarak saptamış ve seröz sıvılardaki düşük duyarlılığın düşük basil yükü ile ilişkili olduğunu ifade etmişlerdir (12). Sharma ve arkadaşları, lenf nodu biyopsi örnekleri ve apse örneklerine kıyasla seröz sıvı örneklerinde saptama duyarlılığının düşük olmasını düşük basil yükü ve bu sıvılardaki PCR inhibitörü varlığına dayandırmaktadır (13). Bu çalışmalara benzer şekilde çalışmamızda altı yalancı negatif örneğin beşi periton ve plevra sıvısı gibi seröz SIVı örnekleriydi. Dünya Sağlık Örgütü'nün 2014'te akciğer ve akciğer dışı tüberkülozun hızlı tanısında otomatize nükleik asit amplifikasyon teknolojisine dair politika güncellemesinde plevra sıvısının, plevral tüberkülozun tanısında kullanılan yöntemden bağımsız olarak uygun bir örnek olmadı̆̆ı, biyopsi materyalinin tercih edilmesi önerisi mevcuttur (14). Du ve arkadaşları, Xpert MTB/RIF sisteminin plevra sıvısı örneklerinde MTC DNA'sı saptama duyarlılığını $\% 43,6$; plevra biyopsi örneklerinde \%85,5 olarak belirlemişlerdir. Plevra biyopsi örneklerinde MTC DNA'sının saptanma duyarlılığı plevra sıvısından anlamlı olarak yüksektir (15). Plevral tüberküloza benzer şekilde peritoneal tüberküloz tanısında, klinik şüpheye rağmen periton sıvısından yapılan değerlendirmeler sonuçsuz kaldığında peritoneal biyopsi seçeneği göz önünde bulundurulmalıdır (16).

Çalışmamızda yayma ve kültür negatif olup PCR'de pozitiflik saptanan 11 örneğin yedisinde (dört apse, iki doku, bir periton biyopsi örneği) PCR pozitifliğini hastanın kliniği, patoloji ve/veya radyoloji bulguları desteklemiş̧ir, böylece kültür negatif olmasına rağmen hastalara tüberküloz tanısı koyulabilmiştir. İki hastada antitüberküloz tedavi altında örnek alınması nedeniyle kültürde pozitiflik saptanamadığı düşünülmüştür, bu hastaların birinde tüberküloz menenjiti ön tanısı ile BOS miktarı yetersiz olduğundan sadece Xpert MTB/RIF pozitifliği ile hastaya antitüberküloz tedavi başlanmıştır. Tüberküloz menenjiti hayatı tehdit eden acil bir patoloji olduğundan, moleküler yöntemler kliniği uyumlu hastalarda ilk basamak tanı testi olarak kullanılıp, konvansiyonel metodlara tercih edilebilir (17). PCR pozitifliği üzerine başlanan antitüberküloz tedavi altında alınan ikinci BOS örneğinde yayma ve kültür negatif, PCR tekrar pozitif saptanmıştır. Nükleik asit amplifikasyon testleri, ölü basillerin saptanma olasıllı̆̆ı nedeniyle tedavi takibinde kullanılmamalıdır. Tedavi sırasında pozitiflik saptanması aktif hastalık anlamına gelmemektedir (18). Laboratuvar sonuçlarımız "Pozitif sonuç canlı basili göstermez, kültür ile doğrulanmalıdır." yorumuyla raporlanmaktadır.

Crohn tanısı alan hastadaki yalancı pozitifliğin (2018), aynı çalışmada pozitiflik saptanan farklı bir hasta örneğinden çapraz kontaminasyon nedeniyle olabileceği düşünülmüştür. Obasanya ve arkadaşları, akciğer örnekleriyle yaptıkları çalışmada FluoroType MTB'nin özgüllüğünün kültür ve Xpert MTB/RIF'e kıyasla düşük olduğunu, bunun örnek hazırlama aşamasında çapraz 
kontaminasyona bağlı olabileceğini belirtmişlerdir. Bu problemin özellikle eğitimli teknik personel sıkıntısı olan laboratuvarlarda manuel DNA ekstraksiyon kiti olan FluoroLyse yerine otomatize GenoXtract kitinin kullanılarak aşılabileceğinin altı çizilmiştir (19).

FluoroType MTB'nin 2018'de duyarlılığı \%76,92 ve 2019'da \%62,5 bulunmuştur. Testin 2018 ve 2019 'daki performans farkı, çalışmaya dahil edilen örneklerin toplama yöntemlerindeki farklılık, değişken basil yükü ve 2019 yılında daha az kültür pozitif vaka olmasından kaynaklı olabileceği düşünülmüştür (20). GeneXpert ve FluoroType sistemlerinde farklı klinik örnekler çalışılmış ve farklı klinik örnekler için duyarlılık ve özgüllük oranları verilmiştir. Bu çalışmamızın bir kısıtıılığıdır.

Farklı klinik tablolara neden olabilmesi, hasta örneklerinin sıklıkla invaziv prosedürler ile elde edilmesi ve az sayıda basil ile büyük hasarlar oluşturabilmesi gibi nedenlerle akciğer dışı tüberküloz tanısı ve yönetimi akciğer tüberkülozuna göre daha güçtür. Yaymanın negatif olduğu düşük basil yüküne sahip vakalarda moleküler yöntemler tanı ve antitüberküloz tedavinin özellikle İnsan Bağışıklık Yetmezliği Virüsü (HIV) enfeksiyonu gibi riskli hasta gruplarında hızlı başlanması açısından önemli bir avantaj sağlar (20). Kültür, altın standart tanı yöntemi olsa da, çalışmamızdaki hasta örneklerinde görüldüğü gibi PCR pozitifliğinin hastanın kliniği, görüntüleme ve diğer laboratuvar bulgularıyla birlikte tanı koymada kritik bir rol oynadığı göz önünde bulundurulmalıdır.

Etik Komite Onayı: Bu çalışma, Marmara Üniversitesi Tıp Fakültesi Klinik Araştırmalar Etik Kurulu'nun onayı ile gerçekleştirilmiştir (Protokol Kodu: 09.2020.676, Tarih: 12.06.2020).

\section{ÇIKAR ÇATIŞMASI}

Yazarlar çıkar çatışması bildirmemiştir.

\section{YAZAR KATKISI}

Anafikir/Planlama: AKY, RCS, NÜ

Analiz/Yorum: AKY, RCS, NÜ

Veri sağlama: NÜ, ND, UK

Yazım: NÜ, ND, UK

Gözden Geçirme ve Düzeltme: AKY, RCS

Onaylama: AKY

\section{KAYNAKLAR}

1. Norbis L, Alagna R, Tortoli E, Codecasa LR, Migliori GB, Cirillo DM. Challenges and perspectives in the diagnosis of extrapulmonary tuberculosis. Expert Rev Anti Infect Ther 2014; 12(5): 633-47.

2. World Health Organization (WHO). Global tuberculosis Report 2019. Geneva: World Health Organization; 2019. Available from: https://www.who.int/tb/publications/global_report (Accessed date: 5 Sept 2020).

3. Kara F, Kabasakal E, Yıldırım A, Mutlu SM, Baykal F. Türkiye'de Verem Savaşı 2019 Raporu. Sağlık Bakanlığı Ankara, 2020. Available from: https://hsgm.saglik.gov.tr/tr/ tuberkuloz-haberler/turkiye-de-verem-savas-2019-raporu. html (Accessed date: 1 Sept 2020).

4. Opota O, Mazza-Stalder J, Greub G, Jaton K. The rapid molecular test Xpert MTB/RIF ultra: towards improved tuberculosis diagnosis and rifampicin resistance detection. Clin Microbiol Infect 2019; 25(11): 1370-6.

5. Zürcher K, Ballif M, Kiertiburanakul S, Chenal H, Yotebieng M, Grinsztejn B, et al. Diagnosis and clinical outcomes of extrapulmonary tuberculosis in antiretroviral therapy programmes in low- and middle-income countries: a multicohort study. J Int AIDS Soc 2019; 22(9): e25392.

6. HAIN LifeScience. FluoroType ${ }^{\circledR}$ MTB Ver 1.0 instructions for use. Nehren: Document IFU-611-01; 2015.

7. Hofmann-Thiel S, Hoffmann H. Evaluation of Fluorotype MTB for detection of Mycobacterium tuberculosis complex $D N A$ in clinical specimens from a low-incidence country. BMC Infect Dis 2014; 14: 59.

8. Blakemore R, Story E, Helb D, Kop J, Banada P, Owens MR, et al. Evaluation of the analytical performance of the Xpert MTB/RIF assay. J Clin Microbiol 2010; 48(7): 2495-501.

9. Ozkutuk N, Surucüoglu S. Orta prevalanslı bölgede akciğer ve akciğer dışı tüberküloz tanısında Xpert MTB/RIF testinin değerlendirilmesi [Evaluation of the Xpert MTB/RIF assay for the diagnosis of pulmonary and extrapulmonary tuberculosis in an intermediate-prevalence setting]. Mikrobiyol Bul 2014; 48(2): 223-32.

10. World Health Orhanization (WHO). Report for WHO: A multicentre non-inferiority diagnostic accuracy study of the Ultra assay compared to the Xpert MTB/RIF assay. Geneva, Switzerland; Foundation for Innovative New Diagnostics 2017. Available from: https://www.who.int/tb/publications/2017/ XpertUltra/en/ (Accessed date: 7 Sept 2020).

11. Perez-Risco D, Rodriguez-Temporal D, Valledor-Sanchez I, Alcaide F. Evaluation of the Xpert MTB/RIF Ultra Assay for Direct Detection of Mycobacterium tuberculosis Complex in Smear-Negative Extrapulmonary Samples. J Clin Microbiol 2018; 56(9): e00659-18. 
12. Liu R, Li J, Tan Y, Shang Y, Li Y, Su B, et al. Multicenter evaluation of the acid-fast bacillus smear, mycobacterial culture, Xpert MTB/RIF assay, and adenosine deaminase for the diagnosis of tuberculous peritonitis in China. Int I Infect Dis 2020; 90: 119-24.

13. Sharma SK, Kohli M, Chaubey J, Yadav RN, Sharma R, Singh $B K$, et al. Evaluation of Xpert MTB/RIF assay performance in diagnosing extrapulmonary tuberculosis among adults in a tertiary care centre in India. Eur Respir J 2014; 4(4): 1090-3.

14. World Health Organization (WHO). Automated real-time nucleic acid amplification technology for rapid and simultaneous detection of tuberculosis and rifampicin resistance: Xpert MTB/RIF assay for the diagnosis of pulmonary and extrapulmonary TB in adults and children: policy update. World Health Organization 2013. Available from: https://apps.who.int/iris/handle/10665/112472 (Accessed date: 14 Oct 2020).

15. Du J, Huang Z, Luo Q, Xiong G, Xu X, Li W, et al. Rapid diagnosis of pleural tuberculosis by Xpert MTB/RIF assay using pleural biopsy and pleural fluid specimens. I Res Med Sci 2015; 20(1): 26-31.

16. Suzana S, Ninan MM, Gowri $M$, Venkatesh K, Rupali P, Michael JS. Xpert MTB/Rif for the diagnosis of extrapulmonary tuberculosis--an experience from a tertiary care centre in South India. Trop Med Int Health 2016; 21(3): 385-92.
17. Kohli M, Schiller I, Dendukuri N, Dheda K, Denkinger CM, Schumacher SG, et al. Xpert ${ }^{\circledast}$ MTB/RIF assay for extrapulmonary tuberculosis and rifampicin resistance. Cochrane Database Syst Rev 2018; 8(8): CD012768.

18. TC Sağıık Bakanlı̆̆ı. Tüberküloz Tanı ve Tedavi Rehberi, Ankara 2019. Available from: https://hsgm.saglik.gov.tr/ depo/birimler/tuberkuloz_db/haberler/Tuberkuloz_Tani_ Ve_Tedavi_Rehberi_/Tuberkuloz_Tani_ve_Tedavi_Rehberi. pdf (Acessed date: 2 Dec 2020)

19. Obasanya J, Lawson L, Edwards T, Olanrewaju O, Madukaji $L$, Dacombe R, et al. FluoroType MTB system for the detection of pulmonary tuberculosis. ERJ Open Res 2017; 3(2): 00113-2016.

20. Mechal Y, Benaissa E, El Mrimar N, Benlahlou Y, Bssaibis F, Zegmout $A$, et al. Evaluation of GeneXpert MTB/RIF system performances in the diagnosis of extrapulmonary tuberculosis. BMC Infect Dis 2019; 19(1): 1069. 